\title{
EVERYDAY STORIES IN A FOREST: MULTIMODAL MEANING-MAKING WITH OJIBWE ELDERS, YOUNG PEOPLE, LANGUAGE, AND PLACE
}

\author{
Mary Hermes ${ }^{1}$ \\ University of Minnesota \\ Meixi \\ University of Minnesota \\ Mel M. Engman \\ Queen's University Belfast \\ James McKenzie \\ University of Arizona
}

\begin{abstract}
Expanding efforts in Indigenous language revitalization and reclamation (e.g., Henne-Ochoa et al., 2020; Leonard, 2008, 2019; McIvor, 2020) highlight the ecology of relations that language is embedded in across communities and land. A critically important aspect of understanding these relations is a language's "livingness" in place; that is, the context of where the language emerged and where the language is intertwined and has lived within lands and stories for generations. Taking up this intersection of language, land, and story, our paper examines the multimodal language of storying the land in Ojibwe in episodes from video-recorded intergenerational (Elders and youth) walks in the woods that were a part of an Indigenous languages documentation project. We focused on interactional episodes involving storywork (Archibald, 2008) and conducted interaction analysis (Jordan \& Henderson, 1995). Indigenous scholarship (e.g., Noori, 2013; Simpson, 2014) articulates the importance of stories as Indigenous theory, and this paper builds on this work, illustrating how everyday storying and walking on lands (Marin \& Bang, 2018) are rich contexts for language learning and reclamation.
\end{abstract}

Keywords: Indigenous language reclamation, story, land, place, Ojibwe

Citation: Hermes, M., Meixi, Engman, M. M., \& McKenzie, J. (2021). Everyday stories in a forest: Multimodal meaning-making with Ojibwe Elders, young people, language, and place. WINHEC: International Journal of Indigenous Education Scholarship, 16(1), pp. 267-301. http://dx.doi.org/10.18357/wj1202120289. Special Issue on Indigenous Language Revitalization: Innovation, Reflection and Future Directions, Guest Co-Editors Drs. Onowa McIvor and Kari A. B. Chew.

\footnotetext{
${ }^{1}$ Correspondence: Mary Hermes, University of Minnesota, mhermes@umn.edu. (Authorship: Equal distribution across all four authors.)
} 


\section{Introduction}

The purpose of this study is to respond directly to expanding efforts in Indigenous language documentation and reclamation (e.g., Henne-Ochoa et al., 2020; Leonard, 2008, 2019; McIvor, 2020) that highlight the ecology of community and land-based relations in which language is embedded. A critically important aspect of understanding these relations is a language's "livingness" in place; that is, the context of where the language emerged, where the language intertwines and lives within lands and stories for generations. We focus on this intersection of storying, walking, and land and their role in Indigenous language reclamation. Stories hold pedagogical potential (e.g., Archibald, 2008; Basso, 1996; Iseke \& Brennus, 2011; Simpson, 2014) and are part of human learning and becoming, with language as both living content and context for use.

This study presents data and analysis from an Ojibwe language documentation project that brings bilingual youth and First Speakers together on land to illustrate the significance of story, language, and place for everyday intergenerational sense-making. We aim to expand how story is considered in Indigenous language scholarship by moving beyond notions of story that tend to be tethered to the significance of a story's content. Instead, we present storying as a practice whose "livingness" is held and distributed across human bodies, memory, language, and land. We also seek to extend recent work that views walking, reading, and storying land as important intergenerational cultural practices (Bang \& Marin, 2015; Bang et al., 2014; Marin \& Bang, 2018; Meixi, 2019) by documenting intergenerational walks in Ojibwe in local forests to deepen our understanding of storying and re-storying relations. 
We ask: What is the role of stories in intergenerational sense-making in Ojibwe language on Ojibwe land?

\section{An Intervention to Documentation: Reclamation as Living in Relation}

Recent work in Indigenous language documentation and reclamation challenges the idea of "dying languages" that reduces Indigenous languages to verbally-produced data that should be captured as code text before they "die" (Child Language Research and Revitalization Working Group, 2017; Fitzgerald, 2017; Leonard, 2018, 2020; Manatowa-Bailey, 2008). Perley (2012) refers to this practice as "mortuary linguistics," an approach "where linguists go out to find the last speakers of dying languages and record their last words" (p. 140). We align with critical documentation scholarship that rejects ideas of language as a static, settled object, plucked from time and place (Coulthard, 2014; Meek, 2007), and we turn to Indigenous scholarship that says Indigenous languages are a living relative, not a dying object (Deloria et al., 2012; Hohepa \& Mika, 2018; Kawagley, 1995; Leonard, 2017; Nicholas, 2009; Simpson, 2014; Wildcat, 2005), even if some are sleeping or awakening (Baird, 2016; Baldwin et al., 2013; Leonard, 2008;).

Rejection of these deficit discourses of "death" and "extinction" (e.g., Amery, 2009; Austin \& Sallabank, 2018; Dobrin et al., 2007) requires that Indigenous language projects work from Indigenous epistemological concepts of language rather than structural linguistics (HenneOchoa et al., 2020; Hermes, 2005; Hermes et al., 2012; Leonard, 2017, 2020; McCarty et al., 2019; Smith, 2013). For instance, Leonard's $(2008,2018,2020)$ use of the term reclamation describes efforts that are defined by communities, emphasizing projects that center 
decolonizing as a goal. Community projects such as language camps, community language nights, language houses, and community-driven classes can range in scale from single gatherings to multi-site collaborative initiatives that span many years (Báez, 2016; DementiLeonard \& Gilmore, 1999; Johnson, 2017; McKenzie, 2020; Oberly et al., 2015). Not limited to institutional spaces, such efforts often take place on Indigenous lands and waters, in community homes and centers. They often aim at re-elevating and creating accessibility to Indigenous concepts of language for new generations of learners and can include as much about lifeway and relational identity teachings as they do about language (Baldwin et al., 2013; McCarty \& Lee, 2014). As documentation projects increasingly include community collaboration (e.g., Penfield et al., 2008) issues of the purpose, products, and if or how community members might be involved in the initial design are emerging (Austin \& Sallabank, 2018; Hermes et al., 2012; Nathan \& Fang, 2013).

This paper is based on data from a documentation-as-reclamation project,,$^{2}$ affectionately referred to hereafter as "Forest Walks." Each of the authors came to the project via different paths and with different experiences, relations, and investments in Ojibwe language, Indigenous language, and place.

- Mary Hermes. Waabishkiimiigwan, gaa-wiinid a'aw Mooka'am. Nimiigwechiwenimininim ingiw maanidoo, gaa-wiidookaajig. Baatayiinowag. Memindage niminkwenimaa, a'aw minomooyehn, Zhaangweshiban. As Principal Investigator (PI), Mary originated the forest walks project, which built on other Indigenous sustainability, land, and language efforts. She is a Lac Courte Oreilles

\footnotetext{
${ }^{2}$ National Science Foundation DEL/BCS grant no. 1664510 
Ojibwe community member, a scholar/language activist, and co-founder of the Waadookodaading Ojibwe Language Immersion School, the immersion school attended by the young bilingual speakers in the documentation project. Also, she is a Professor of Curriculum and Instruction at the University of Minnesota Twin Cities in her spare time.

- Meixi joined the forest walks team in January 2020 as Hokchiu land-based learning scientist, former middle school mathematics teacher, and current postdoctoral fellow in American Indian Studies at the University of Minnesota. Meixi draws from her prior experiences co-design teaching and learning with Indigenous families to support the video data analysis process and the roles of walking and storying lands in language reclamation.

- Mel Engman was once one of Mary's graduate students and is a descendant of white settlers to the Great Lakes region. Mel is an applied linguist and learner of Ojibwe language who has been involved with school, family, and community language projects since 2012. She took part in Forest Walks data collection and analysis as part of her work with Mary's non-profit organization Grassroots Indigenous Multimedia (GIM). She is now a Lecturer in Education at Queen's University Belfast.

- James McKenzie. A Diné graduate student with experience in Diné language and culture revitalization and immersion programming on the Navajo Nation, James began work with the project as research assistant to Waabishkiimiigwan. He was appreciative to join the project in 2019 and to contribute to the analysis while he was a graduate student at University of Minnesota focused on Indigenous immersion education. 
Informed by both the community language camps on land and the centuries-old Indigenous traditions of walking and reading land, the project aimed to capture and document interactions on land in Ojibwe. Following the work of Chicago American Indian Center Researchers (Bang et al., 2014), youth and Elders were asked to go on walks in the woods on the Lac Courte Oreilles reservation. They were outfitted with point-of-view cameras, asked to talk about whatever they wished, and return in about 20 minutes. The seeming simplicity of the project design is its most extraordinary feature. The youth participants were willing and able to stay in Ojibwemowin for the entirety of each walk. (See: Hermes et al., under review, for expanded discussion of documentation methods.)

Set at the Lac Courte Oreilles Band of Lake Superior Chippewa reservation (LCO) in Northern Wisconsin, youth were invited from the Waadookodaading Ojibwe Immersion School to be a part of this project. Part of the decision to choose this particular community to work with comes from community membership and a long-term relationship with this school, but mainly because it is outstanding in its ability to cultivate language use among youth within the school. Youth at the school have consistently been acquiring high levels of proficiency in Ojibwemowin (Sullivan, 2018), and within the 20 years since it was established, this is having ripple effects on the wider language reclamation community.

In this documentation-as-reclamation project, there were 14 walks, ranging from 10-30 minutes, which were transcribed and translated over the course of two years and will soon 
be available at the American Philosophical Society. ${ }^{3}$ This corpus served as data for our research team, which used a micro-interactional analysis to describe the interactions found in this paper. Meeting weekly for one academic year and one summer, we sorted, coded, analyzed and wrote about the collaboration, inclusion of land, and apprenticeship we see in this data. This paper focuses on a single one-minute interaction, part of a longer 14-minute walk, chosen for its relationship to storying the land.

\section{Theoretical framework}

\section{Why Everyday Stories Matter for Reclamation}

This project draws on Indigenous scholarship that articulates the importance of stories as Indigenous theory as emergent from Indigenous lands and language (e.g., Archibald, 2008; Brayboy, 2005; Noori, 2013; Simpson, 2014). In this paper, we use theory to refer to guiding principles that shape how one understands and enacts their unique place-based relationships with others, humans, and more-than-human. Theory functions as an ecology of living teachings that guide how one learns, understands, acts, and makes decisions. Simpson (2014) describes how stories generate theory "from the ground up" (p. 7) for even the youngest community members who, by holding the story, imbue it with power. This theorymaking relies on stories as "anchors" that maintain throughlines of meaning across individuals and communities through time and space.

\footnotetext{
${ }^{3}$ Archives were deposited to the American Philosophical Society in June 2020. Due to Covid-19, they are still in the process of being uploaded but will be publicly available when the upload is complete.
} 
Indigenous scholars have drawn on Jo-ann Archibald's (2008) scholarship on "storywork" to explore how Indigenous communities rely on stories and traditions of storytelling to know, listen, and teach. Importantly, the interrelated processes of storytelling and storylistening reveal the "interrelatedness between the intellectual, spiritual (metaphysical values and beliefs and the Creator), emotional, and physical (body and behavior/action) realms" (Archibald, 2008, p. 11). These stories, storytelling, and storylistening reflect land-based lifeways in place (Marker, 2018; Ortiz, 1992) and reflect important protocols of asking for stories and receiving them that index values of reciprocity and require labor and responsibility on the part of the hearer (Iseke, 2013). This paper makes visible how such theory-making is active, not passive; and the actions of story-making are critical to Indigenous ways of knowing (Kawagley, 1995) in concert with place (Marker, 2018).

Stories connect our understandings of human, more-than-human, and land-based relations. As Marker (2018) explains, "(n)arrative meaning is inseparable from place and a metaphysically saturated sentient geography" (pp. 458-459). Language, story, and land are entangled rather than distinct entities. In many instances, stories live in and with an "ensouled landscape" (Marker, 2018, p. 458). This perspective on stories and storytelling is foundational to our framing of stories as embedded in ways of being, ways of knowing, and place. For language reclamation this contributes to expanded concepts of language as localized (rather than decontextualized) and multimodal (rather than solely oral/verbal). Additionally, Indigenous epistemologies do not impose a binary separation between the nature of things that are sacred and everyday, as if everything were only one thing or the other (Deloria, 2009; Marker, 2018). Rather, meaning can be made in interaction and 
relations with the large and the small. Thus, attention to stories encourages attention to educational possibilities rooted in storying that is sewn by interwoven threads of the spiritual, concrete, relational, experiential, and linguistic.

To localize this theory in our data, that is in Ojibwemowin, is important in this context to discuss what we mean by stories. In Ojibwemowin there two distinct words (with many more variations) for "story": aadizookaan and dibaajimowin. The first is defined as a sacred story or a spirit, the second as a narrative story. Importantly, Ojibwemowin also makes a distinction in the grammatical gender of these two words. Aadizookaan is "animate" whereas dibaajimowin's grammatical gender is "inanimate," a distinction that can be approximated in terms of the difference between the pronouns "she," "he," and "they" as compared to the pronoun "it." We note this here because it demonstrates the ways in which Ojibwe worldview is reflected in its grammatical structure. ${ }^{4}$ Aadizookaan as "animate" is alive and has agency of their own. There are many other words for the narrative kind of story that use the same final word ending, for example, wiinaajimo (she tells a dirty story), babaamaajimo (she spread the word about), danaajimo (she tells the story of a certain place). While this may seem to contradict the above notion that there is no binary separation between the everyday and the sacred, these types of stories are distinct in the 0jibwe language and culture.

Although it is beyond the scope of this piece to distinguish all the ways "stories" are told in Ojibwe context and further delineate categories that those specific Ojibwe words about

\footnotetext{
${ }^{4}$ Animacy in Ojibwemowin linguistics refers to a gendered category, and it is debatable if these categories always mean "living" in English translations. Although aadizookaanag do have spiritual and aliveness significance, this does not follow with all animate nouns.
} 
stories, talk, and conversation create, we can contribute to sense-making of aadizookaanag within the context of the ordinary. While we do not know what the categories in Ojibwe thinking might be, we are pointing to the limitations of an English translated dictionary. That is, aadizookaanag are not necessarily distinct from dibaajimowinan because one is sacred and one is not; sacred and secular are Western categories. With that distinction aside, we turn our attention to discuss what one aadizookaan (sacred story) looks like within the context of interaction on land, that is, a sacred story that is used in meaning making in the everyday.

\section{Connecting Everyday Stories and Interaction}

The story we write about here was told on walks in the forest, a story that came about in everyday interaction in the springtime. What does it mean to think of stories as embedded in interactions, not as abstracted from a context? We ask this because, at times, the content of Indigenous stories is appropriated out of context and romanticized (Sarris, 1993). This decontextualization runs counter to the idea at the heart of this study-that everyday practices are reinforced, redundant, and part of constellations of practices that are deeply cultural (Rogoff, 2014). Because of this, we see the contexts of these stories as worthy of study as well. For example, we know that it is not the content of the bedtime stories that is important and distinct in Heath's (1982) well known example, but rather the way the stories are told, their place within interactions and routines in relationships, that distinguish one class culture from another. 
We draw on this understanding of storying as theory-making in collaboration, in place as part of a documentation-as-reclamation study of intergenerational Ojibwe language. Acknowledging the traces of formal, traditional storytelling that inform sense-making in everyday interactions, we see how informal collaborative storymaking in the language holds tremendous potential for understanding how inquiry is generated and knowledge produced in place.

\section{Methods: Multimodal Interaction Analysis}

\section{Study Context and Design}

This study of intergenerational walks in the woods takes place on forest lands that are the ancestral home of Anishinaabe people around the Great Lakes region of what is now the United States. Most walks took place on or near the reservation lands of the Lac Courte Oreilles Band during the spring and summer months between April 2016 and May 2018. Many of the First Speaker Elders and young bilingual speakers (students and graduates of Waadookodaading Ojibwe Language Immersion school) who took part in this Ojibwe language documentation project had participated in previous documentation and reclamation projects, and all were financially compensated for their labor and expertise.

Starting with an acknowledgement of the relationality holding together the participants and language and place, each recording day began with offerings of tobacco (Hermes et al., 2012). Tobacco is offered in the Ojibwe tradition to ask someone to participate, and in turn participants put tobacco out on the land to acknowledge our relations there. Participants were then divided into small groups consisting of at least one Elder and one bilingual young 
person, they were outfitted with microphones and head-mounted GoPro cameras, and asked to go for a walk in the woods lasting no more than 20 minutes. No specific prompts were given; rather, they were instructed to talk about anything they wanted to. The young people knew each other well, as all of them came from the tight-knit community that sustains and is sustained by Waadookodaading. Some Elders were familiar community figures, while others were not. Introductions were made prior to the start of data collection and were also subsequently enfolded into the early stages of each walk as participants made conversation about their families, their clans, and their home communities and got to know each other as they walked.

\section{Data Analysis}

Each walk was logged, transcribed, and translated into ELAN software by a bilingual Ojibwe language specialist affiliated with the project who worked independently and later with the speakers to check accuracy. Transcripts were then divided into "episodes" based on attentional content, that is, one episode is determined by group attention being oriented around a topic or environmental phenomenon. For instance, one episode called Waagaagin (fiddlehead fern) features two young speakers and one Elder as they puzzle over a fern shoot pulled from the forest floor. The boundaries of the episode begin when the first young speaker discovers and calls attention to the fern shoot, including all of the talk, movement, and land-based engagements that are seen as relating to the fern shoot, and the episode ends when attention has shifted away from the fern. 
We used transcripts side-by-side with videos to guide our multimodal interaction analysis (Hall \& Stevens, 2016; Jordan \& Henderson, 1995) of the walks. As interaction analysis involves unmotivated looking at first, we did not initially search for stories. However, transcripts were augmented after each data session to include salient features of interaction and sense-making that were not visible in the first round of transcription and translation. As the research team watched and re-watched videos, we enriched the flat, code-focused transcripts to include wide-ranging non-verbal, multimodal features of interaction through various transcription techniques such as inclusion of screenshots, multimodal "toon strips," and including land as an animate interlocutor in the interaction. These augmented transcripts were subsequently compared with the movies over and over again to ensure that they represented the source data as thoroughly as possible.

Through a close, micro-analysis of the co-operative action (Goodwin, 2018) in these rich transcripts and their corresponding movies, the research team then identified episodes that showed evidence of storytelling (Brayboy, 2005), storywork (Archibald, 2008), and/or (re)storying the land (Bang et al., 2014; Marin \& Bang, 2018) as theory-building in concert with language and with place.

\section{Findings}

This study demonstrates the flexibility of story as a resource for sense-making on and with land. In our example, we present one episode (extracted as four excerpts) that illustrates how shared knowledge of traditional stories serves as a resource in coordination with verbal and non-verbal communication, and with land as an animate interlocutor in the interaction. 
The human participants in this walk are Joe Nayquonabe, ${ }^{5}$ a first speaker Elder from Mille Lacs Band of Ojibwe, and two bilingual young people from Waadookodaading Ojibwe Language Immersion School named Bea and Lexi. As the trio walks the path in the woods, their attention turns to features of the land that are referred to in a traditional story. The story is one that is only told under specific circumstances by those who heard it and learned it under similar conditions. As the group references the story and reads it in the land, we see evidence of the practices and protocols associated with traditional storytelling in the talk about the story, illustrating intergenerational expertise with the entanglements of story, land, and language.

\section{Excerpt 1: Manidoo, aa, gii-namadabi}

Excerpt 1 (see Table 1; see Appendix A for transcription conventions) begins approximately 5 minutes into the walk that illustrates how stories in the forest emerged while the triad was reading and walking lands in a kind of fluid synchrony (Mejía-Arauz et al., 2018). In this extract, Bea and Lexi build on each other's observations in an additive way to further the group's engagement and observation of the forest.

Bea begins by turning to her companions and saying in lines 1 and 2, "indaa-gagwemikaamin, aa, mitig ezhinaagwak yo'ow" (we should find a tree that looks like this). As she says the word "yo' ow" (this), Bea uses her right arm and hand to make a sort of U-shape. Joe and Lexi follow Bea's lead, and they turn to look at the land (See Joe's and Lexi's point-ofview [POV] shots in line 3). As Lexi's attention shifts from Bea to the land, Lexi locates just

\footnotetext{
${ }^{5}$ Real names were used at the request of the participants. 
such a tree off to the right of the trail, pointing in its direction with her arm (line 4), saying, "im[aa!" (there!). Lexi builds upon Bea's invitation to further direct the group's attention towards the cluster of trees, and all three turn to look deeper into the woods (lines $5 \& 6$ ). Bea similarly adds onto Lexi's observation, saying "manidoo, aa, gii-namadabi" (a spirit sat there) in line 7 and sustains the group's keen attention with land again saying "imaa" (there).

\section{Table 1}

Transcript Part 1: Manidoo, aa, gii-namadabi (A spirit sat there)

\begin{tabular}{|c|c|c|c|}
\hline & Spkr & Verbal & Non-Verbal \\
\hline 1 & Bea & $\begin{array}{l}\text { indaa-gagwe-mikaamin, aa, mitig (.) } \\
\text { we should find a tree }\end{array}$ & $\begin{array}{l}\text { on the word "mitig," raises hand to eye } \\
\text { level, with palm turned perpendicular } \\
\text { to the ground }\end{array}$ \\
\hline 2 & & $\begin{array}{l}\text { ezhinaagwak yo'ow }= \\
\text { that looks like this }\end{array}$ & \\
\hline 3 & Land & $=$ & \\
\hline 4 & Lexi & $\begin{array}{l}\text { hh. im[aa! } \\
\text { there }\end{array}$ & $\begin{array}{l}\text { extends arm straight, pointing off the } \\
\text { trail to the right of Joe }\end{array}$ \\
\hline 5 & $\begin{array}{l}\text { Joe } \\
\text { Bea } \\
\text { Lexi }\end{array}$ & & $\begin{array}{l}\text { all three direct gaze to the woods in the } \\
\text { direction that Lexi pointed }\end{array}$ \\
\hline
\end{tabular}




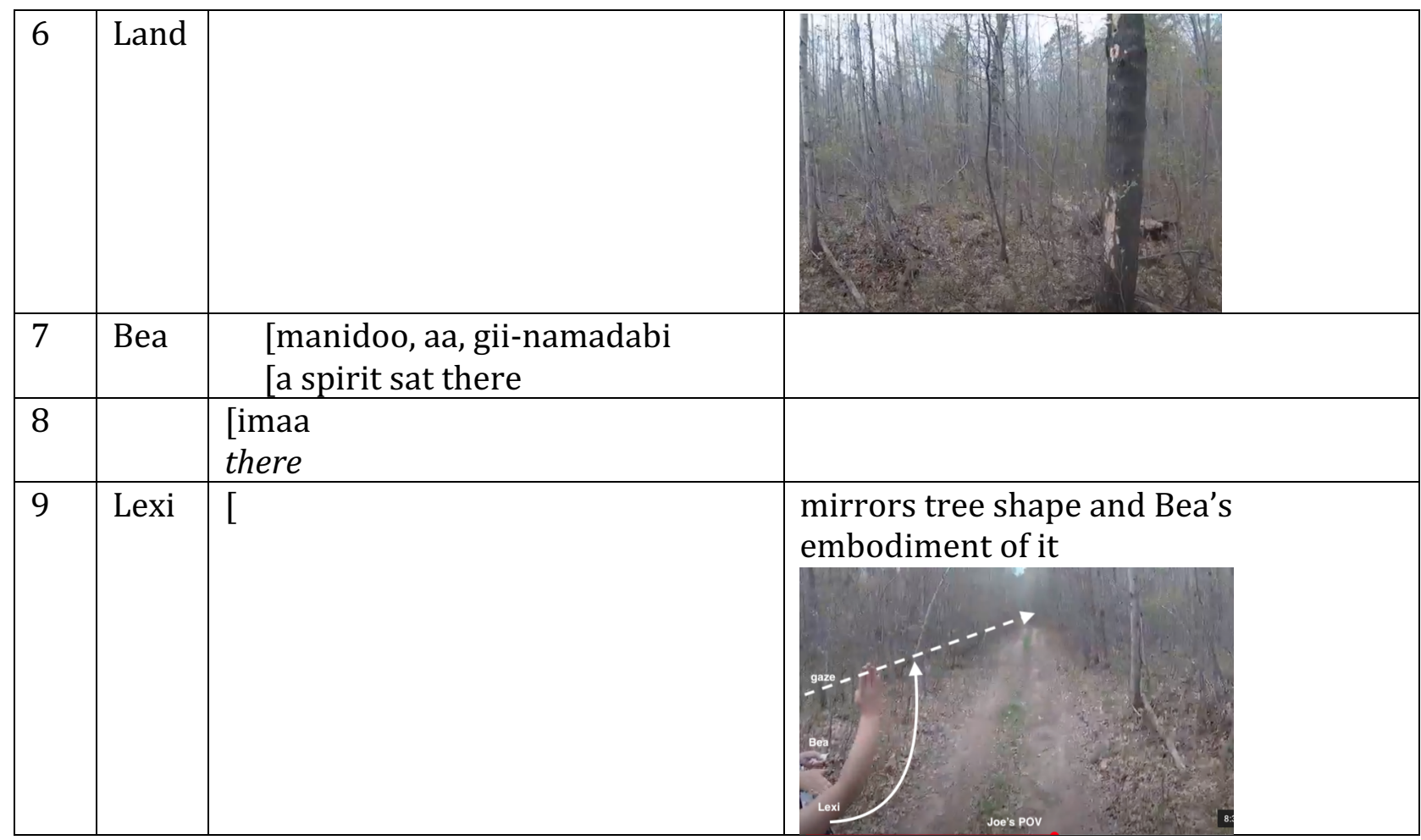

Bea's use of the affix "gii-" to signal the past tense in line 7 suggests she was drawing from a previous experience or heard a story that a spirit "sat there," indicating that a spirit was there in the past. Bea knew what to look for because she has seen this kind of tree before from previous land-based encounters. At the same time, Bea seems to be hesitant around saying who that spirit was as well. In a similar fluid collaboration as if one organism with multiple parts, Lexi uses her arms to mirror Bea's initial movements, embodying the tree that they are paying attention to. Both Bea's and Lexi's coordinated use of talk and embodiment indicate an experiential knowledge with place that is both cognitive and embodied. They begin a sequence of collaborative sense-making between the humans and land in the interaction that involves the perceptual field, language, bodies, and story memory as resources for constructing understanding together. This continues to unfold in Excerpt 2. 


\section{Excerpt 2: Wenabozho namadabid}

In this extract (see Table 2), Joe follows up with a question to Bea and Lexi, asking "Wenabozho namadabid?" (Wenabozho is sitting?) in line 11, naming Wenabozho directly as potentially the spirit in the tree. It is significant that the youth do not utter Wenabozho's name-oral protocols dictate not to speak of this powerful spirit unless the ground is frozen. Joe, as an Elder, says the name but the girls refrain. In that utterance, Joe also changes "giinamadabi" (uttered by Bea in line 7) to "namadabid," with the reframing of tenses suggesting the very present way that Wenabozho is still sitting there in the land, reaffirming the livingness of stories within the forest. Bea affirms that and is amused by Joe's indication of Wenabozho there in the woods.

As the triad continue to keenly observe the trees in the forest, Joe adds onto the narrative of Wenabohzo in the woods. This time he switches from the verb "namadabid?" (sitting) to "gana[waabaminang" (watching us). Namadabi is an animate intransitive verb, whereas ganawaabam is an animate transitive verb, meaning that both the "watcher" and the one being watched are necessarily animate. This verb shift signals the relational nature of watching between Wenabozho and themselves, and it indexes the living interrelationships that are embedded with stories. Rather than single narrative events that teach "about," stories are read, lived, and perceived with land in ways that can strengthen our unique understandings of who we are within these systems of land-based relationships. 
Table 2

Transcript Part 2: Wenabozho namadabid (Wenabozho sitting)

\begin{tabular}{|c|c|c|c|}
\hline & Spkr & Verbal & Non-Verbal \\
\hline 10 & Joe & $\begin{array}{l}\mathrm{o} \\
\mathrm{oh}\end{array}$ & \\
\hline 11 & & $\begin{array}{l}\text { Wenabozho namadabid?= } \\
\text { Wenabozho sitting? }\end{array}$ & \\
\hline 12 & Bea & $=\mathrm{yah}=$ & smiles, laughs \\
\hline 13 & Land & & $\sqrt{11}$ \\
\hline 14 & Lexi & $\begin{array}{l}=\text { nashke imaa! } \\
=\text { look there }\end{array}$ & points toward same direction as earlier \\
\hline 15 & Joe & & $\begin{array}{l}\text { turns toward the right of the trail, in } \\
\text { general direction Lexi is pointing }\end{array}$ \\
\hline 16 & & $\begin{array}{l}\text { gana[waabaminang } \\
\text { watching us }\end{array}$ & \\
\hline 17 & Bea & $\begin{array}{l}\text { [gegaa go, izhinaagwad } \\
\text { [almost, it looks like }\end{array}$ & \\
\hline 18 & Land & & \\
\hline 19 & Joe & $\begin{array}{l}\text { oh gegaa, henh? } \\
\text { oh almost, yeah? }\end{array}$ & \\
\hline
\end{tabular}




\begin{tabular}{|l|l|l|l|}
\hline 20 & & $\begin{array}{l}\text { looks back over to girls who look at him, } \\
\text { then looks back to the tree, continuing to } \\
\text { walk }\end{array}$ \\
\hline
\end{tabular}

\section{Extract 3: "Awenesh gaa-wiindamawik i'iwe?" (who told you that?)}

Though the group's forward movement continues, the storyline of Wenabozho's chair holds the group's attention. Bea directly refers to story memory in line 28 with "o nimikwendaan i'iw" (Oh I remember that), building on the idea of Wenabozho sitting and watching them. Joe looks out at the tree as he says "bangii" (a little), perhaps building on the earlier hedged assertions that it "almost" looked like Wenabozho was watching them. After the triad establishes a common understanding and perception that it almost looks like Wenabozho is watching you, Joe pauses to ask Bea and Lexi who they have learned these stories from. Bea and Lexi respond to this starting in line 32 and show us how the genealogies of stories are part of reconnection to land and language.

As the triad continues down the trail, Joe opens up a conversation around the learning relationships of stories. As Joe's gaze returns to the trail, he stops walking and asks Bea "awenesh gaa-wiindamawik i'iwe?" (who told you that?). Bea and Lexi both stop and look at Joe, almost recognizing the gravity of the question he just posed. Bea answers that she heard it from her friend, Niizhoodewii (line 34). Joe's gaze then moves from Bea back to the trail. Bea is still thinking about who she learned this story from and offers a second person to her genealogy of the story (line 36), Waawaakeyaash, a founding teacher at Waadookodaading. Lexi, who is four years younger than Bea, places herself within this web of relations too, 
saying in line 39 "Waawaakeyaash nigikinoo'amaaged” (Waawaakeyaash is my teacher). Not completely unlike citational practice in academic work, in Indigenous ways of knowing, acknowledging the origins of stories and the relational way they travel is important and reinforces distributed community knowledge. These practices help us understand and place ourselves within genealogies of Indigenous knowledge-for Lexi and Bea, this includes deepening ideas of themselves as historical actors, what unique responsibilities they hold, and how these responsibilities came to be (Gutiérrez, 2008). Drawing on stories as part of theory-making, Indigenous practices go beyond the purely citational function, they help make sense of how an individual and the knowledge they steward are connected within a network of relationships. Joe's question made the importance of this clear to the two young people.

\section{Table 3}

Transcript Part 3: Awenesh gaa-wiindamawik i'iwe? (Who told you that?)

\begin{tabular}{|c|c|c|c|}
\hline & Spkr & Verbal & Non-Verbal \\
\hline 28 & Bea & $\begin{array}{l}\text { o nimikwendaan [i'iw } \\
\text { Oh I remember [that }\end{array}$ & \\
\hline 29 & Joe & $\begin{array}{l}\text { [bangii } \\
\text { a little }\end{array}$ & $\begin{array}{l}\text { gaze moves "on trail" again, forward } \\
\text { facing }\end{array}$ \\
\hline 30 & $\begin{array}{l}\text { Joe } \\
\text { Bea } \\
\text { Lexi }\end{array}$ & & all stop walking \\
\hline 31 & Joe & $\begin{array}{l}\text { awenesh gaa-wiindamawik i'iwe? } \\
\text { who told you that? }\end{array}$ & \\
\hline 32 & Lexi & & both stop and look at Joe \\
\hline
\end{tabular}




\begin{tabular}{|c|c|c|c|}
\hline & Bea & & \\
\hline 33 & Joe & $\begin{array}{l}\text { imaa namadabid aw manidoo, } \\
\text { that the spirit was sitting there }\end{array}$ & \\
\hline 34 & Bea & $\begin{array}{l}\text { um:: (.) niwiijiiwaagan bezhig } \\
\text { Niizhoodewii } \\
\text { one of my friends, Niizhoodewii }\end{array}$ & \\
\hline 35 & Joe & $\begin{array}{l}\text { o ahaw } \\
\text { oh okay }\end{array}$ & looks from kids to the trail \\
\hline 36 & Bea & $\begin{array}{l}\text { miinawaa indinendam } \\
\text { Waawaakeyaash gaye wiin } \\
\text { and I think Waawaakeyaash also }\end{array}$ & starts walking again as she speaks \\
\hline 37 & $\begin{array}{l}\text { Joe } \\
\text { Lexi }\end{array}$ & & both start to walk slowly again \\
\hline 38 & Joe & $\begin{array}{l}\text { o } \\
o h\end{array}$ & \\
\hline 39 & Lexi & $\begin{array}{l}\text { Waawaakeyaash } \\
\text { nigikinoo'amaaged } \\
\text { Waawaakeyaash is my teacher }\end{array}$ & facing Joe \\
\hline 40 & $\begin{array}{l}\text { Bea } \\
\text { Lexi }\end{array}$ & & both stop walking \\
\hline 41 & Joe & $\begin{array}{l}\text { o aah } \\
\text { oh }\end{array}$ & gaze turns to both girls \\
\hline
\end{tabular}

Joe responds to Bea's offering of two of her teachers with a verbal recognition that he coordinates with his motion and his gaze. He briefly stops walking to look directly at both WINHEC: International Journal of Indigenous Education Scholarship 
girls, acknowledging their story memory and the network of community relationships that hold the story. By asking "awenesh gaa-wiindamawik i'iwe?" (who told you that?) Joe aims to better understand the knowledge carried by Lexi and Bea in ways that acknowledge and extend learning beyond just the people, times, and places of the present, and that are shaped by the relationships that have nurtured and sustained them. As such, stories as our groundup theories (Simpson, 2014), passed down and transformed across generations, within the genealogies of clan, group, and place have served as relational repositories of knowledge. Sharing these knowledges in immersion schools like Waadookodaading is a powerful move of re-establishing connection within and across groups in language and cultural revitalization, particularly in the face of cultural genocide aimed at quashing these knowledge systems. In this sense, referencing who and where we learned these stories is an act of reclamation itself.

\section{Extract 4: Epilogue: “Ganawaabaminaang” (He is watching us)}

This episode concerning the storying of Wenabozho and springtime land ends as group attention shifts to an animal in the perceptual field. However, the livingness of this storying is evident in talk that occurred 5 minutes later. Though it could be considered an episode of its own, we treat this fourth excerpt (see Table 4) as a sort of epilogue to the episode that comprises the first three excerpts because the interaction that unfolds continues building upon the interactional, co-operative substrate (Goodwin, 2013, 2018) that was established 5 minutes earlier. Joe stops walking and calls attention to a tree to the right of the path. He coordinates his cessation of movement with the extension of his arm and pointed finger, gesturing toward the tree and asks the girls if they see how they (some animals) climb up 
the tree and store something there (lines 43 and 45). Lexi follows Joe's direction and as she looks out at the land she builds on his observation, saying in line 49: "Ganabaj ogii-namadab imaa bezhig" (I think one sat there). Joe and Bea affirm this assertion in lines 50 and 51 . Then, as they begin walking again, Joe appears to connect Lexi's words in this moment with the utterance from 5 minutes earlier that used the very same words to refer to Wenabozho. Joe simply says "Wenabozho" and looks to Bea who laughs, acknowledging the shared memory of their collaboration earlier in the walk. As Joe and Bea continue their movement down the trail, Joe says "ganawaabaminang" (he is watching us) in line 55, revoicing the storying that took place 5 minutes earlier (line 16), re-reading it into the land.

\section{Table 4}

Transcript Part 4: Ganawaabaminaang (He is watching us)

\begin{tabular}{|l|l|l|l|}
\hline 42 & Spkr & \multicolumn{1}{|c|}{ Verbal } & \\
\hline 43 & Joe & $\begin{array}{l}\text { gigikendaan ezhichigewaad e, } \\
\text { do you know what they did }\end{array}$ & $\begin{array}{l}\text { Stops walking, raises hand and points } \\
\text { to upper tree tops off to the right }\end{array}$ \\
\hline 44 & Bea & & $\begin{array}{l}\text { Turns to face Joe, then follows his finger } \\
\text { pointing toward the treetops off to the } \\
\text { right of the trail }\end{array}$ \\
\hline
\end{tabular}




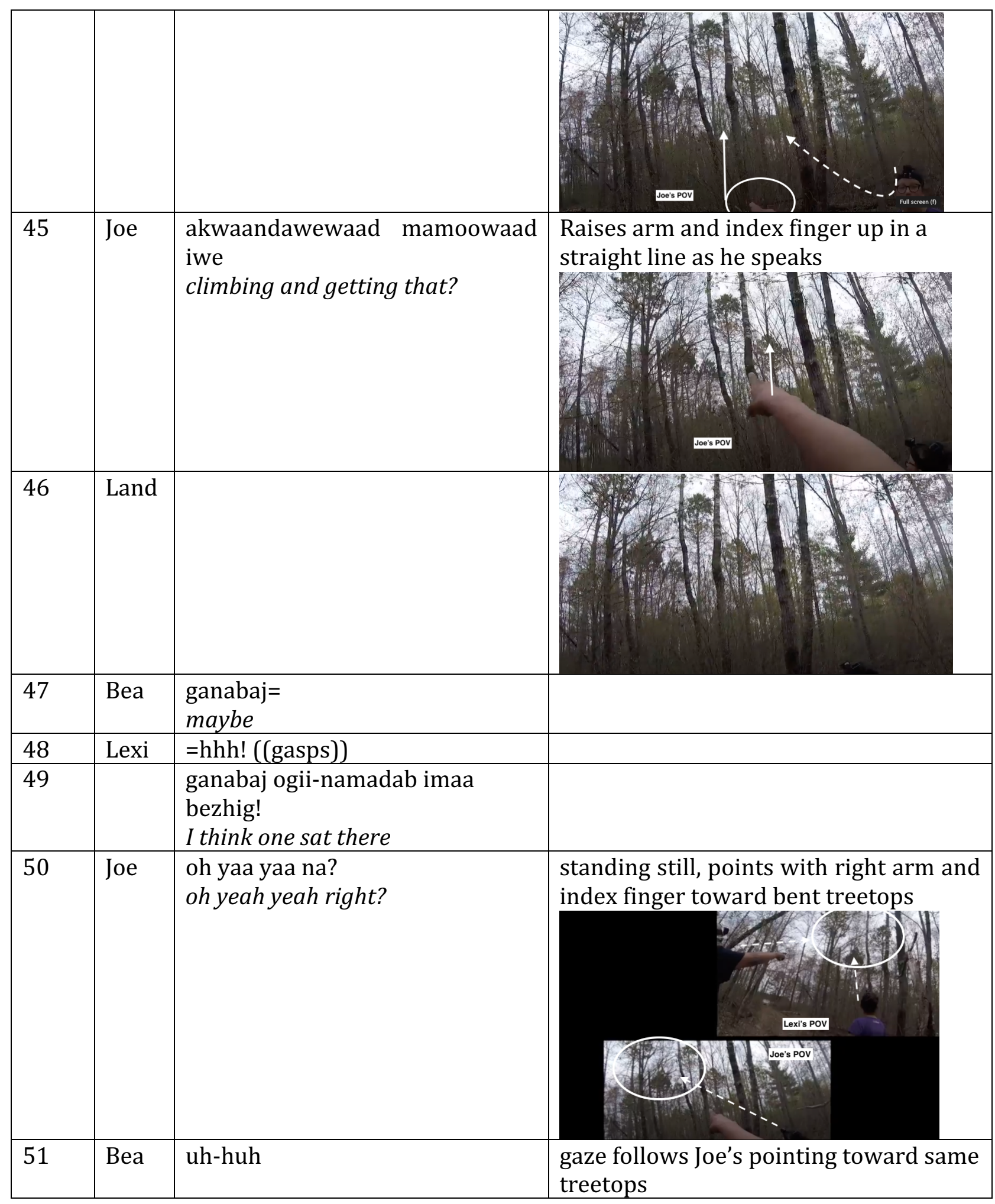




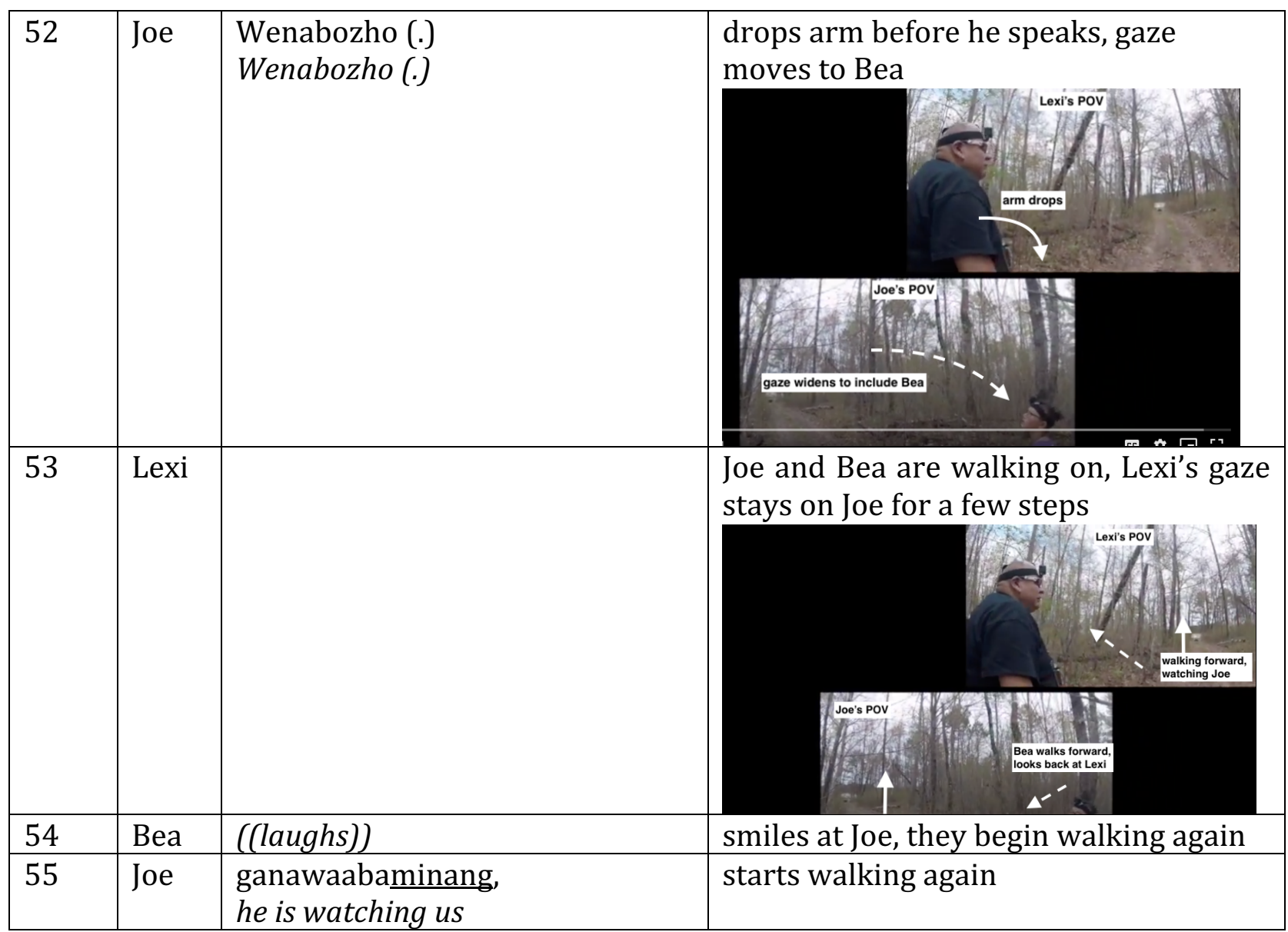

In the four excerpts comprising this episode, a traditional story about Wenabozho and a trace he leaves on the land anchors over 50 turns of intergenerational Ojibwe language interaction. The evidence of the story that the young 0jibwe speakers read into the land are as relevant to the interaction as the circumstances of the story's telling. The story itself is not told, but rather serves as a reference for reading land, for whole body language use, and for performing Ojibwe identity in collaboration. This is theory-making. An experience-based hypothesis is proposed, evidence is gathered and collectively analyzed, and a genealogy of the existing knowledge is provided. All of this is bound up in story knowledge that serves as a resource for learning and using language in place. 


\section{Conclusions}

Indigenous people, in every place they lived, found ways to address these questions of survival and sustainability in profoundly elegant ways. And through the seeking, making, sharing, and celebrating of these natural relationships, they came to perceive themselves as living in "a sea of relationships." In each of the "places," they lived they learned the subtle, but all important, language of relationship. (Cajete \& Williams, 2020, p. 1714)

In this paper, we suggest that intergenerational, everyday storying with lands is a language of relationship, a reminder of our relationships with human and more-than-human worlds. These excerpts illustrate that storying is a multimodal practice for making meaning, remembering, and learning. The storying that is demonstrated here in interaction on land in the springtime reflects a story's "livingness"; it accompanies and frames the walks. Its content does not need to be retold to be a resource for theory-making. Rather, the protocols that hold certain stories as "sacred" are reflected in the practices of the everyday—walking, reading, embodying the land, and remembering stories as shared points of reference across generations.

For education, this work has implications around how Indigenous language reclamation is part of reclaiming relations. Storying was a way for young people to demonstrate expert knowledge of the story not by re-telling it word-for-word, but by reading it into the land with the support of their language and bodies and referencing it carefully according to protocols. For scholarship addressing the teaching and learning of Indigenous languages, this helps 
reimagine how we might recognize "proficiency." Typical associations of the verbal output associated with the linguistic competence of re-telling a story are turned sideways when we instead recognize competence in embodied, distributed knowledge of storying with place. This relational approach refuses to lift stories from their contexts and instead views "proficiency" as an understanding of how to hold a story in a wider ecology of knowing. Linguistic systems are only a part of storying for reclamation. It also involves social, genealogical, geographical, climatological, and ecological systems. How a story becomes known to someone, the who, when, and where of it, is entangled with the story knowledge. For the youth in this study, their sources of the Wenabozho story are multigenerational, that is, a friend or a teacher at school, legitimizing both peers and adults as teachers. The inclusion of this genealogy is also important to the theory-making work of storying, where how you know is as important as what you know. And on land, the knowing with becomes significant as well.

\section{It's Like Making a Dance With the Trees That Explains Life}

This "knowing with" is especially the case in stories that relate concepts and ideal relationships to the forces of the natural environment and all the living things therein. Metaphoric thinking is closely involved with the process of imagining in creativity (Cajete \& Williams, 2020, p. 1713). Living in the colonial structures of what language is, and so what reclamation means, need to be centered around relationality, especially with land and other human communities. When learning language is defined in a Western academic way, it becomes narrowed to language acquisition, devoid of context and relationship making. An individual can learn or acquire a language, but Indigenous reclamation involves re- 
establishing relationships, relationality which must extend to include the land from which the language itself grew. In our efforts to reclaim Indigenous language, it is not just the product of language acquisition we are after. The process of how we reconnect with each other, the context of our plant and animal relatives: those are just as important as using the correct morphemes and syntax.

In this case, oral language and storytelling on land affords the opportunity for the imagination of the participants to recall the spirits that inhabit the land. Beyond a metaphor, the phrase, "Wenaboozhoo is watching us" is deeply symbolically encoded, and an immediate literal reminder, replete with layers of meaning for the past and present way of being. They breathe life into the story through noticing the trees in the forest and sharing a sense of what this means. While the meaning of the story is shared, each participant who hears the story is free to find the most salient lessons for themselves and connect them to the moment that they are living. In this kind of theory making, the analysis is not extricated and expounded on, it is left ongoing for continuous meaning making as living Ojibwe futures. 


\section{Glossary $^{6}$}

Aadizookaan: (animate noun) 1. A sacred story, 2. A spirit

Babaamaajimo: (verb animate intransitive) s/he spreads the word about

Danaajimo: (verb animate intransitive) s/he tells a story in a certain place

Dibaajimowin: (inanimate noun) a narrative, a story

Wiinaajimo: (verb animate intransitive) s/he tells a dirty story

\section{About the Authors}

Mary Hermes is a Lac Courte Oreilles Ojibwe community member, a scholar/language activist, director of the non-profit organization Grassroots Indigenous Multimedia, and a Professor of Curriculum \& Instruction at the University of Minnesota.

Meixi is a Hokchiu scholar and learning scientist involved in family and land-based Indigenous education and technologies at the University of Minnesota.

Mel Engman is a white settler learner of Ojibwe involved in school, family, and community language projects, and is a Lecturer at Queen's University Belfast.

James McKenzie is a Diné graduate student focused on Indigenous language immersion and language and culture-based education at the University of Arizona.

${ }^{6}$ Translated definitions supported by the Ojibwe People's Dictionary: https://ojibwe.lib.umn.edu/ 


\section{References}

Amery, R. (2009). Phoenix or relic? Documentation of languages with revitalization in mind. Language Documentation, 3(2), 11.

Archibald, J. (2008). Indigenous storywork: Educating the heart, mind, body, and spirit. UBC Press.

Austin, P. K., \& Sallabank, J. (2018). Language documentation and language revitalizationSome methodological considerations. In L. Hinton, L. Huss, \& G. Roche (Eds.), The Routledge handbook of language revitalization. Routledge.

Báez, G. P. (2016). Addressing the gap between community beliefs and priorities and researchers' language maintenance interests. In G. P. Báez, C. Rogers, \& J. E. R. Labrada (Eds.), Language documentation \& revitalization in Latin American contexts (pp. 165-194). Walter de Gruyter.

Baird, J. L. D. (2016). Wopanaak language reclamation program: Bringing the language home. Journal of Global Indigeneity, 2(2), 7.

Baldwin, D., Baldwin, K., Baldwin, J. \& Baldwin, J. (2013). myaamiaataweenki oowaaha: "Miami spoken here." In L. Hinton (Ed.), Bringing our languages home: Language revitalization in families (pp. 3-18). Heyday Books.

Bang, M., Curley, L., Kessel, A., Marin, A., Suzukovich, E. S., \& Strack, G. (2014). Muskrat theories, tobacco in the streets, and living Chicago as Indigenous land. Environmental Education Research, 20(1), 37-55. https://doi.org/10.1080/13504622.2013.865113

Bang, M., \& Marin, A. (2015). Nature-culture constructs in science learning: Human/nonhuman agency and intentionality. Journal of Research in Science Teaching, 52(4), 530-544.

Basso, K. H. (1996). Wisdom sits in places: Landscape and language among the Western Apache. University of New Mexico Press.

Brayboy, B. (2005). Toward a tribal critical race theory in education. The Urban Review, $37(5), 425-446$.

Cajete, G. A., \& Williams, D. R. (2020). Eco-aesthetics, metaphor, story, and symbolism: An Indigenous perspective. In A. Cutter-Mackenzie-Knowles, K. Malone, \& E. Barratt Hacking (Eds.), Research handbook on childhoodnature: Assemblages of childhood and nature research (pp. 1707-1733). Springer International Publishing. 
Child Language Research and Revitalization Working Group. (2017). Language documentation, revitalization, and reclamation: Supporting young learners and their communities. Education Development Center. http://www.edc.org/languagedocumentation-revitalization-and-reclamation

Coulthard, G. S. (2014). Red skin, white masks: Rejecting the colonial politics of recognition. University of Minnesota Press.

Deloria, V. (2009). C.G. Jung and the Sioux traditions: Dreams, visions, nature, and the primitive. Spring Books.

Deloria, V., Wildcat, D., \& Wilkins, D. (2012). Metaphysics of modern existence. Fulcrum Publishing.

Dementi-Leonard, B., \& Gilmore, P. (1999). Language revitalization and identity in social context: A community-based Athabascan language preservation project in western interior Alaska. Anthropology \& Education Quarterly, 30(1), 37-55.

Dobrin, L., Austin P.K., \& Nathan, D. (2007). Dying to be counted: The commodification of endangered languages in documentary linguistics. In P. K. Austin, O. Bond, \& D. Nathan (Eds.), Proceedings of Conference on Language Documentation and Linguistic Theory. School of Oriental \& African Studies (SOAS), University of London. https://www.dnathan.com/eprints/dnathan etal 2007 commodification.pdf

Fitzgerald, C. M. (2017). Understanding language vitality and reclamation as resilience: A framework for language endangerment and "loss" (commentary on Mufwene). Language, 93(4), e280-e297.

Goodwin, C. (2013). The co-operative, transformative organization of human action and knowledge. Journal of Pragmatics, 46(1), 8-23. https://doi.org/10.1016/j.pragma.2012.09.003

Goodwin, C. (2018). Co-operative action. Cambridge University Press.

Gutiérrez, K. D. (2008). Developing a sociocritical literacy in the third space. Reading Research Quarterly, 43(2), 148-164.

Hall, R., \& Stevens, R. (2016). Interaction analysis approaches to knowledge in use. In A. A. diSessa, M. Levin, \& N. J. S. Brown (Eds.), Knowledge and interaction (pp. 88-124). Routledge.

Heath, S. B. (1982). What no bedtime story means: Narrative skills at home and school. Language in Society, 11(1), 49-76.

Henne-Ochoa, R., Elliott-Groves, E., Meek, B.A., \& Rogoff, B. (2020). Pathways forward for Indigenous language reclamation: Engaging Indigenous epistemology and learning 
by observing and pitching in to family and community endeavors. The Modern Language Journal, 104, 481-493.

Hermes, M. (2005). "Ma'iingan is just a misspelling of the word wolf”: A case for teaching culture through language. Anthropology \& Education Quarterly, 36(1), 54-71.

Hermes, M., Bang, M., \& Marin, A. (2012). Designing Indigenous language revitalization. Harvard Educational Review, 82(3), 381-402.

Hermes, M., Engman, M. M., McKenzie, J., \& Meixi (under review). What documenting for reclamation looks like: Ojibwemowin Forest Walks. Language Documentation \& Conservation.

Hohepa M., \& Mika C. (2018) Language-culture-education: Problem and potential: An introduction. In E. McKinley \& L. Smith (Eds.), Handbook of Indigenous education. Springer.

Iseke, J. (2013). Indigenous storytelling as research. International Review of Qualitative Research, 6(4), 559-577. https://doi.org/10.1525/irqr.2013.6.4.559

Iseke, J., \& Brennus, B. (2011). Learning life lessons from Indigenous storytelling with Tom McCallum. In G. J. S. Dei (Ed.), Indigenous philosophies and critical education (pp. 245-261). Peter Lang.

Jefferson, G. (2004). Glossary of transcript symbols with an introduction. In G. Lerner (Ed.), Conversation analysis: Studies from the first generation, (pp. 13-31). John Benjamins Publishing.

Johnson, M. K. (2017). Syilx language house: How and why we are delivering 2,000 decolonizing hours in Nsyilxcn. Canadian Modern Language Review, 73(4), 509-537. https://doi.org/10.3138/cmlr.4040

Jordan, B., \& Henderson, A. (1995). Interaction analysis: Foundations and practice. The Journal of the Learning Sciences, 4, 39-103.

Kawagley, O. A. (1995). Yupiaq worldview: A pathway to ecology and spirit. Waveland Press.

Leonard, W. Y. (2008). When is an "extinct" language not extinct? Miami, a formerly sleeping language. In K. A. King, N. Shilling-Estes, L. Fogle, J. J. Lou, \& B. Soukup (Eds.), Sustaining linguistic diversity: Endangered and minority languages and language varieties (pp. 23-33). Georgetown University Press.

Leonard, W. Y. (2017). Producing language reclamation by decolonising "language." In W. Y. Leonard \& H. De Korne (Eds.), Language documentation and description, Vol. 14, 15-36. EL Publishing. 
Leonard, W. Y. (2018). Reflections on (de)colonialism in language documentation. In B. McDonnell, A. L. Berez-Kroeker, and G. Holton. (Eds.), Reflections on language documentation 20 years after Himmelmann 1998. (Language Documentation \& Conservation Special Publication no. 15., pp. 55-65). University of Hawai'i Press.

Leonard, W. Y. (2020). Musings on Native American language reclamation and sociolinguistics. International Journal of the Sociology of Language, 2020(263), 8590. https://doi.org/10.1515/ijsl-2020-2086

Manatowa-Bailey, J. (2008, May 2-4). Waiting for the mythical dictionary: The language researcher within Native communities. [Conference presentation]. Native American Languages in Crisis. Conference at University of Pennsylvania.

Marin, A., \& Bang, M. (2018). "Look it, this is how you know:" Family forest walks as a context for knowledge-building about the natural world. Cognition and Instruction, 36(2), 89-118. https://doi.org/10.1080/07370008.2018.1429443

Marker, M. (2018). There is no place of nature; there is only the nature of place: Animate landscapes as methodology for inquiry in the Coast Salish territory. International Journal of Qualitative Studies in Education, 31(6), 453-464. https://doi.org/10.1080/09518398.2018.1430391

McCarty, T., \& Lee, T. (2014). Critical culturally sustaining/revitalizing pedagogy and Indigenous education sovereignty. Harvard Educational Review, 84(1), 101-124. https://doi.org/10.17763/haer.84.1.q83746nl5pj34216

McCarty, T. L., Nicholas, S. E., \& Wigglesworth, G. (Eds.). (2019). A world of Indigenous languages: Politics, pedagogies and prospects for language reclamation. Multilingual Matters.

McKenzie, J. (2020). Approaching from many angles: Seeing the connections for our languages to live. The Modern Language Journal, 104(2), 501-506.

McIvor, O. (2020). Indigenous language revitalization and applied linguistics: Parallel histories, shared futures? Annual Review of Applied Linguistics, 40, 78-96. https://doi.org/10.1017/S0267190520000094

Meek, B. A. (2007). Respecting the language of elders: Ideological shift and linguistic discontinuity in a northern Athapascan community. Journal of Linguistic Anthropology, 17(1), 23-43. https://doi.org/10.1525/jlin.2007.17.1.23

Mejía-Arauz, R., Rogoff, B., Dayton, A., \& Henne-Ochoa, R. (2018). Collaboration negotiation: Two ways of interacting suggest how shared thinking develops. Current Opinion in Psychology, 23, 117-123. 
Nathan, D., \& Fang, M. (2013). Re-imagining documentary linguistics as a revitalization-driven practice. In M. Jones \& S. Ogilvie (Authors), Keeping languages alive: Documentation, pedagogy and revitalization (pp. 42-55). Cambridge University Press. http://doi.org/10.1017/CB09781139245890.006

Nicholas, S. E. (2009). "I live Hopi, I just don't speak it" - The critical intersection of language, culture, and identity in the lives of contemporary Hopi youth. Journal of Language, Identity \& Education, 8(5), 321-334. https://doi.org/10.1080/15348450903305114

Noori, M. (2013). Anishinaabemowin: Language, family and community. In L. Hinton (Ed.), Bringing our languages home: Language revitalization for families (pp. 118-140). Heydey Press.

Oberly, S., White, D., Millich, A., Cloud, M. I., Seibel, L., Ivey, C., \& Cloud, L. (2015). Southern Ute grassroots language revitalization. Language Documentation, 9, 20.

Ortiz, S. J. (1992). Woven stone. University of Arizona Press.

Penfield, S. D., Serratos, A., Tucker, B. V., Flores, A., Harper, G., Hill, J., \& Vasquez, N. (2008). Community collaborations: Best practices for North American Indigenous language documentation. International Journal of the Sociology of Language, 2008(191), 187202.

Perley, B. C. (2012). Zombie linguistics: Experts, endangered languages and the curse of undead voices. Anthropological Forum, 22(2), 133-149. https://doi.org/10.1080/00664677.2012.694170

Rogoff, B. (2014). Learning by observing and pitching in to family and community endeavors: An orientation. Human Development, 57(2-3), 69-81. https://doi.org/10.1159/000356757

Sarris, G. (1993). Keeping slug woman alive: A holistic approach to American Indian texts. University of California Press.

Simpson, L. B. (2014). Land as pedagogy: Nishnaabeg intelligence and rebellious transformation. Decolonization: Indigeneity, Education \& Society, 3(3), 1-25.

Smith, P. L. T. (2013). Decolonizing methodologies: Research and Indigenous Peoples. Zed Books Ltd.

Wildcat, D. R. (2005). Indigenizing the future: Why we must think spatially in the twenty-first century. American Studies, 46(3/4), 417-440. 


\section{Appendix A}

\section{Transcription conventions $^{7}$}

\begin{tabular}{|l|l|}
\hline $\begin{array}{l}\text { ikidowinan } \\
\text { words }\end{array}$ & $\begin{array}{l}\text { Ojibwe on top in unmodified text } \\
\text { English translation below in italics }\end{array}$ \\
\hline$=$ & Latching \\
\hline$()$. & Brief, untimed pause \\
\hline word- & Repair, self-interruption \\
\hline[ & Overlapping turns \\
\hline$(())$ & Gesture, non-verbal communication \\
\hline. & Falling intonation \\
\hline, & Slightly rising (or "listing") intonation \\
\hline$?$ & Rising intonation \\
\hline$<$ word $>$ & Slower speech \\
\hline$>$ word $<$ & Faster speech \\
\hline${ }^{\circ}$ word & \\
\hline word & Very quiet speech \\
\hline
\end{tabular}

${ }^{7}$ Adapted from: Jefferson, G. (2004). Glossary of transcript symbols with an introduction. In G. Lerner (Ed.), Conversation analysis: Studies from the first generation (pp. 13-31). John Benjamins Publishing. 